\title{
ELECTROLYTE PATTERNS IN BANTU BABIES BORN SPONTANEOUSLY AND BY CAESAREAN SECTION
}

\author{
BY \\ E. U. ROSEN \\ From the Paediatric Unit, Baragwanath Hospital, Johannesburg, South Africa
}

(RECEIVED FOR PUBLICATION MARCH 21, 1961)

Great interest has been centred during recent years on the renal physiology and the milieu interieur of newborn infants. However, so far no studies have been carried out on newborn Bantus.

Although it is well established that neonatal renal function is immature (McCance and Young, 1941; McCance, 1959), full-term healthy babies delivered spontaneously and without undue difficulty are known to be able to maintain themselves in satisfactory fluid and electrolyte balance provided that they are adequately fed.

It has, however, been shown that in full-term babies who are delivered only after a difficult labour, and also in premature infants, the blood urea tends to rise to well above the normal value on the second day of life (McCance and Widdowson, 1954; Joppich and Wolf, 1958). How the milieu intérieur is affected (if it is affected at all) in babies delivered by caesarean section has, as yet, not been determined.

This study was undertaken $(a)$ to establish the normal values for the blood urea, the serum sodium $(\mathrm{Na})$, chloride $(\mathrm{Cl})$, and potassium $(\mathrm{K})$ and the blood carbon-dioxide combining power $\left(\mathrm{CO}_{2} \mathrm{com}\right.$ bining power) in spontaneously delivered Bantu babies, born at full-term and weighing more than $5 \frac{1}{2} \mathrm{lb}$. (normal babies) during the first three days of life; and $(b)$ to determine the serum electrolyte pattern in the first 10 days of life of full-term, healthy Bantu babies delivered by caesarean section (caesarean babies).

\section{Materials and Methods}

From each of 91 normal babies a specimen of approximately $8 \mathrm{ml}$. blood was taken during the first, second or third day of life. The concentrations of the blood urea, the serum $\mathrm{Na}, \mathrm{K}$, and $\mathrm{Cl}$ and the $\mathrm{CO}_{2}$ combining power were measured in each of these specimens. For a variety of reasons a complete set of readings could not be made on every specimen taken. A total of 88 blood urea readings, 84 serum $\mathrm{Na}$ readings, 87 serum $\mathrm{Cl}$ readings, 82 serum $\mathrm{K}$ readings, and $82 \mathrm{CO}_{2}$ combining power readings was recorded by the end of the survey. The number of readings made for each electrolyte during the first, second and third day of life ranged from 26 to 31 (see Tables 1 to 5).

From each of 120 caesarean babies who were clinically well from birth until their discharge from hospital (usually on the tenth day of life) $8 \mathrm{ml}$. blood were taken on two separate occasions at least 24 hours apart, within their first 10 days of life. The concentration of the blood urea, serum $\mathrm{Na}, \mathrm{Cl}, \mathrm{K}$ and the $\mathrm{CO}_{2}$ combining power was measured in each of these specimens. Again, for a variety of reasons, a complete set of readings could not always be made on each of the specimens taken. A total of 246 blood urea readings, 254 serum Na readings, 246 serum $\mathrm{Cl}$ readings, 226 serum $\mathrm{K}$ readings and $226 \mathrm{CO}_{2}$ combining power readings was recorded by the end of the survey. The number of readings made for each electrolyte during each of the first seven days of life, and on the tenth day of life in these caesarean babies ranged from 25 to 51 . No specimens were obtained on the eighth and ninth days of life.

All the normal babies used in the survey were put to the breast six to 12 hours after delivery and then breastfed every four hours. All the caesarean babies in the survey received their first feed 12 to 24 hours after delivery and were then breast-fed every four hours.

The specimens of blood were obtained from these infants by venepuncture of either the internal jugular or femoral veins, or from the superior sagittal sinus, the latter being approached via the posterior fontanelle, as described by Kunz (1953). The serum $\mathrm{Cl}$ was measured by the method of Schales and Schales (1941), the blood urea by the method of King and Wootton (1956). The $\mathrm{CO}_{2}$ combining power was estimated by the Van Slyke volumetric method (King and Wootton, 1956), and the serum $\mathrm{Na}$ and serum $\mathrm{K}$ were measured by flame photometry (King and Wootton, 1956).

The statistical calculations were carried out as follows:

The mean for number $(\mathrm{N})$ of samples was estimated using the formula:

$$
\bar{x}=\frac{\epsilon x}{N}
$$

The standard deviation for the individual measurements (the biased estimate of the standard deviation) was determined by using the formula:

$$
s=\frac{\epsilon x^{2}}{N}-\bar{x}^{2}
$$


The $95 \%$ confidence interval for the various electrolytes was determined using the formula:

$$
\xi=\bar{x} \pm t \cdot 95 \frac{s}{\sqrt{ } \bar{N}} \text {, where ' } t \text { '.95 is student's } t .
$$

The significant difference tests between the results obtained in normal and in caesarean babies were based on the formula:

$t=\frac{\left(\bar{x}_{1}-\bar{x}_{2}\right)}{\sqrt{\frac{1}{N_{1}}+\frac{1}{N_{2}}} \sqrt{\frac{N_{1} S_{1}^{2}+N_{2} S_{2}^{2}}{N_{1}+N_{2}-2 .}}}$ distributed as ' $t$ ' with $n-2$ degrees of freedom.

\section{Results}

Normal Babies. Table 1 shows that the mean blood urea for 88 babies, aged from a few hours to 3 days, was $26.7 \mathrm{mg} . / 100 \mathrm{ml}$. From the first to the second day of life the mean rose slightly (from 24.5 to $28.6 \mathrm{mg} . / 100 \mathrm{ml}$.), but on the third day of life it had fallen again to $26.8 \mathrm{mg} . / 100 \mathrm{ml}$.

From Table 2 it can be seen that there was little variation in the mean serum $\mathrm{Na}$ between that of the second and third days of life and that the mean for 84 babies in their first three days of life was 135.6 $\mathrm{mEq} /$ litre.

Table 3 shows that the mean serum $\mathrm{Cl}$ rose from $94.3 \mathrm{mEq} /$ litre on the first day of life to 99.8 $\mathrm{mEq} / \mathrm{litre}$ on the third day of life. The mean of 87 readings obtained during this period was 96.5 $\mathrm{mEq} /$ litre.

The mean serum $K$ was higher on the first day of life than on the two following days when the individual means were approximately identical. The mean for the whole of the three-day period was 4.62 $\mathrm{mEq} /$ litre (Table 4).

Table 5 shows that the mean $\mathrm{CO}_{2}$ combining power in 82 babies during the first three days of life was $19.7 \mathrm{mEq} /$ litre, the mean being slightly higher on the first day of life than on each of the following days.

Caesarean Babies. Fig. 1 and Table 6 show that the blood urea rose from a mean of $32.9 \mathrm{mg}$./ $100 \mathrm{ml}$. on the first day of life to $44.1 \mathrm{mg} . / 100 \mathrm{ml}$. on the fourth day, and then fell slowly to $32.5 \mathrm{mg}$./ $100 \mathrm{ml}$. on the seventh day and $17.6 \mathrm{mg} . / 100 \mathrm{ml}$. on the tenth day.

From Table 7 it can be seen that the mean serum $\mathrm{Na}$ showed no definite trend during the first 10 days of life, ranging from $132 \mathrm{mEq} /$ litre on the first day to 138 and $137 \mathrm{mEq} /$ litre on the third and fifth days respectively, and to $134.7 \mathrm{mEq} /$ litre on the tenth day.

Table 8 shows that the mean serum $\mathrm{Cl}$ was 98.6 $\mathrm{mEq} /$ litre on the first day of life. After falling to $96.3 \mathrm{mEq} /$ litre on the second day, it rose steadily
TABLE 1

BLOOD UREA IN NORMAL BABIES DURING FIRST THREE DAYS OF LIFE

\begin{tabular}{c|c|c|c|c}
\hline Day & $\begin{array}{c}\text { No. } \\
\text { of } \\
\text { Samples }\end{array}$ & $\begin{array}{c}\text { Arithmetic } \\
\text { Mean } \\
\text { (mg./100 ml.) }\end{array}$ & $\begin{array}{c}\text { Standard } \\
\text { Deviation } \\
\text { (mg./100 ml. }\end{array}$ & $\begin{array}{c}95 \% \text { Interval } \\
\text { for } \xi \\
\text { (mg./100 ml.) }\end{array}$ \\
\hline 1 & 31 & $\begin{array}{c}24 \cdot 5 \\
28 \cdot 6\end{array}$ & $\begin{array}{c}9 \cdot 0 \\
9 \cdot 5\end{array}$ & $\begin{array}{c}21 \cdot 2-27 \cdot 8 \\
25 \cdot 0-32 \cdot 2 \\
21 \cdot 8-31 \cdot 8\end{array}$ \\
\hline 3 & 30 & $26 \cdot 8$ & 12.6 & 21.6 \\
\hline $1-3$ & 88 & $26 \cdot 7$ & & \\
\hline
\end{tabular}

TABLE 2

SERUM SODIUM IN NORMAL BABIES DURING FIRST THREE DAYS OF LIFE

\begin{tabular}{c|c|c|c|c}
\hline Day & $\begin{array}{c}\text { No. } \\
\text { of } \\
\text { Samples }\end{array}$ & $\begin{array}{c}\text { Arithmetic } \\
\text { Mean } \\
\text { (mEq/litre) }\end{array}$ & $\begin{array}{c}\text { Standard } \\
\text { Deviation } \\
\text { (mEq/litre) }\end{array}$ & $\begin{array}{c}95 \% \text { Interval } \\
\text { for } \xi \\
\text { (mEq/litre) }\end{array}$ \\
\hline 1 & 30 & $134 \cdot 8$ & $5 \cdot 2$ & $132 \cdot 8-136 \cdot 7$ \\
2 & 29 & $136 \cdot 3$ & $4 \cdot 3$ & $134 \cdot 7-138 \cdot 0$ \\
3 & 25 & $136 \cdot 1$ & $4 \cdot 0$ & $134 \cdot 4-137 \cdot 7$ \\
\hline $1-3$ & 84 & $135 \cdot 6$ & & \\
\hline
\end{tabular}

TABLE 3

SERUM CHLORIDES IN NORMAL BABIES DURING FIRST THREE DAYS OF LIFE

\begin{tabular}{|c|c|c|c|c|}
\hline Day & $\begin{array}{c}\text { No. } \\
\text { of } \\
\text { Samples }\end{array}$ & $\begin{array}{l}\text { Arithmetic } \\
\text { Mean } \\
\text { (mEq/litre) }\end{array}$ & $\begin{array}{c}\text { Standard } \\
\text { Deviation } \\
\text { (mEq/litre) }\end{array}$ & $\begin{array}{l}95 \% \text { Interval } \\
\text { for } \xi \\
\text { (mEq/litre) }\end{array}$ \\
\hline $\begin{array}{l}1 \\
2 \\
3\end{array}$ & $\begin{array}{l}30 \\
30 \\
27\end{array}$ & $\begin{array}{l}94 \cdot 3 \\
95 \cdot 8 \\
99 \cdot 8\end{array}$ & $\begin{array}{l}4 \cdot 5 \\
6 \cdot 2 \\
5 \cdot 1\end{array}$ & $\begin{array}{l}92 \cdot 6-95 \cdot 9 \\
93 \cdot 5-98 \cdot 2 \\
97 \cdot 8-101 \cdot 9\end{array}$ \\
\hline $1-3$ & 87 & $96 \cdot 5$ & & \\
\hline
\end{tabular}

TABLE 4

SERUM POTASSIUM IN NORMAL BABIES DURING FIRST THREE DAYS OF LIFE

\begin{tabular}{c|c|c|c|c}
\hline Day & $\begin{array}{c}\text { No. } \\
\text { of } \\
\text { Samples }\end{array}$ & $\begin{array}{c}\text { Arithmetic } \\
\text { Mean } \\
\text { (mEq/litre) }\end{array}$ & $\begin{array}{c}\text { Standard } \\
\text { Deviation } \\
\text { (mEq/litre) }\end{array}$ & $\begin{array}{c}95 \% \text { Interval } \\
\text { for } \xi \\
\text { (mEq/litre) }\end{array}$ \\
\hline 1 & 29 & $4 \cdot 94$ & $0 \cdot 80$ & $4 \cdot 64-5 \cdot 25$ \\
2 & 29 & $4 \cdot 55$ & $0 \cdot 49$ & $4 \cdot 36-4 \cdot 74$ \\
3 & 24 & $4 \cdot 5$ & 0.67 & $4 \cdot 22-4 \cdot 78$ \\
\hline $1-3$ & 82 & $4 \cdot 62$ & & \\
\hline
\end{tabular}

to $104 \mathrm{mEq} /$ litre on the sixth day, only to fall again over the period of the next four days to the mean value of $97.5 \mathrm{mEq} /$ litre on the tenth day.

Table 9 shows that the mean serum $K$ was markedly higher on the first day of life $(5 \cdot 13$ $\mathrm{mEq} /$ litre) than on each of the following nine days. On the second day the mean serum $K$ dropped sharply to $4.5 \mathrm{mEq} / \mathrm{litre}$ and then remained fairly 


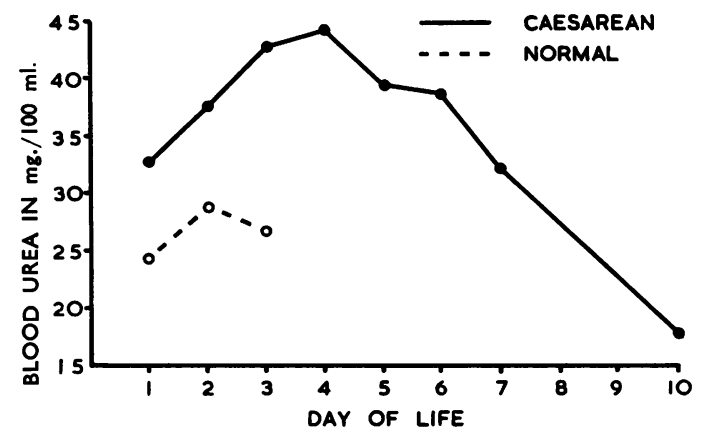

Fig. 1.-Changes in concentration of blood urea during first 10 days of life.

TABLE 5

$\mathrm{CO}_{2}$ COMBINING POWER IN NORMAL BABIES DURING FIRST THREE DAYS OF LIFE

\begin{tabular}{|c|c|c|c|c|}
\hline Day & $\begin{array}{c}\text { No. } \\
\text { of } \\
\text { Samples }\end{array}$ & $\begin{array}{c}\text { Arithmetic } \\
\text { Mean } \\
\text { (mEq/litre) }\end{array}$ & $\begin{array}{c}\text { Standard } \\
\text { Deviation } \\
\text { (mEq/litre) }\end{array}$ & $\begin{array}{l}95 \% \text { Interval } \\
\text { for } \xi \\
\text { (mEq/litre) }\end{array}$ \\
\hline $\begin{array}{l}1 \\
2 \\
3\end{array}$ & $\begin{array}{l}26 \\
30 \\
26\end{array}$ & $\begin{array}{l}20 \cdot 11 \\
19 \cdot 71 \\
19 \cdot 45\end{array}$ & $\begin{array}{l}3 \cdot 00 \\
2 \cdot 72 \\
3 \cdot 66\end{array}$ & $\begin{array}{l}18 \cdot 9-21 \cdot 3 \\
18 \cdot 69-20 \cdot 73 \\
17 \cdot 97-20 \cdot 93\end{array}$ \\
\hline 1-3 & 82 & $19 \cdot 79$ & & \\
\hline
\end{tabular}

TABLE 6

CHANGES IN THE CONCENTRATION OF UREA IN THE BLOOD DURING THE FIRST 10 DAYS OF LIFE IN CAESAREAN BABIES

\begin{tabular}{|c|c|c|c|c|}
\hline Day & $\begin{array}{c}\text { No. } \\
\text { of } \\
\text { Samples }\end{array}$ & $\begin{array}{c}\text { Arithmetic } \\
\text { Mean } \\
(\mathrm{mg} . / 100 \mathrm{ml} .)\end{array}$ & $\begin{array}{c}\text { Standard } \\
\text { Deviation } \\
(\mathrm{mg} . / 100 \mathrm{ml} .)\end{array}$ & $\begin{array}{l}95 \% \text { Confidence } \\
\text { Interval for } \xi \\
\text { (mg. } / 100 \mathrm{ml} .)\end{array}$ \\
\hline $\begin{array}{r}1 \\
2 \\
3 \\
4 \\
5 \\
6 \\
7 \\
10\end{array}$ & $\begin{array}{l}48 \\
30 \\
30 \\
25 \\
29 \\
29 \\
25 \\
30\end{array}$ & $\begin{array}{l}32 \cdot 9 \\
37 \cdot 7 \\
42 \cdot 4 \\
44 \cdot 1 \\
39 \cdot 5 \\
38 \cdot 3 \\
32 \cdot 5 \\
17 \cdot 6\end{array}$ & $\begin{array}{r}16 \cdot 6 \\
16 \cdot 5 \\
25 \cdot 3 \\
28 \cdot 4 \\
24 \cdot 5 \\
23 \cdot 6 \\
36 \cdot 8 \\
6 \cdot 4\end{array}$ & $\begin{array}{l}28 \cdot 1-37 \cdot 7 \\
31 \cdot 6-43 \cdot 8 \\
33 \cdot 0-51 \cdot 8 \\
28 \cdot 3-59 \cdot 8 \\
30 \cdot 2-48 \cdot 8 \\
29 \cdot 3-47 \cdot 3 \\
17 \cdot 3-47 \cdot 7 \\
15 \cdot 2-20 \cdot 0\end{array}$ \\
\hline
\end{tabular}

constant during the next four days. On the seventh day it rose to $4.85 \mathrm{mEq} /$ litre, and the mean serum $\mathrm{K}$ on the tenth day was the same as that on the seventh day.

Table 10 shows that the mean $\mathrm{CO}_{2}$ combining power was at its highest (19.5) during the first day of life. It then fell steadily to $17 \cdot 4$ on the fourth day. After this it showed an overall tendency to rise, reaching $18 \cdot 3$ on the seventh day, this also being the approximate value for the tenth day.

The significant difference tests between the electro-
TABLE 7

CHANGES IN CONCENTRATION OF SERUM SODIUM DURING THE FIRST 10 DAYS OF LIFE IN CAESAREAN BABIES

\begin{tabular}{c|c|c|c|c}
\hline Day & $\begin{array}{c}\text { No. } \\
\text { of } \\
\text { Samples }\end{array}$ & $\begin{array}{c}\text { Arithmetic } \\
\text { Mean } \\
\text { (mEq/litre) }\end{array}$ & $\begin{array}{c}\text { Standard } \\
\text { Deviation } \\
(\mathrm{mEq} / \text { litre })\end{array}$ & $\begin{array}{c}95 \% \text { Confidence } \\
\text { Interval for } \xi \\
(\mathrm{mEq} / \text { litre })\end{array}$ \\
\hline 1 & 51 & $132 \cdot 0$ & $6 \cdot 4$ & $130 \cdot 2-133 \cdot 8$ \\
2 & 28 & $135 \cdot 8$ & $5 \cdot 4$ & $133 \cdot 7-137 \cdot 9$ \\
3 & 30 & $138 \cdot 0$ & $4 \cdot 0$ & $136 \cdot 5-139 \cdot 5$ \\
4 & 34 & $134 \cdot 8$ & $4 \cdot 8$ & $132 \cdot 1-137 \cdot 6$ \\
5 & 29 & $137 \cdot 1$ & $6 \cdot 0$ & $134 \cdot 9-139 \cdot 7$ \\
6 & 29 & $132 \cdot 9$ & $7 \cdot 2$ & $130 \cdot 1-135 \cdot 6$ \\
7 & 25 & $135 \cdot 6$ & $4 \cdot 4$ & $133 \cdot 8-137 \cdot 4$ \\
10 & 28 & $134 \cdot 7$ & $5 \cdot 4$ & $133 \cdot 7-135 \cdot 7$ \\
\hline
\end{tabular}

TABLE 8

CHANGES IN CONCENTRATION OF SERUM CHLORIDE DURING THE FIRST 10 DAYS OF LIFE IN CAESAREAN BABIES

\begin{tabular}{r|c|c|c|c}
\hline Day & $\begin{array}{c}\text { No. } \\
\text { of } \\
\text { Samples }\end{array}$ & $\begin{array}{c}\text { Arithmetic } \\
\text { Mean } \\
\text { (mEq/litre) }\end{array}$ & $\begin{array}{c}\text { Standard } \\
\text { Deviation } \\
\text { (mEq/litre) }\end{array}$ & $\begin{array}{c}\text { 95\% Confidence } \\
\text { Interval for } \xi \\
\text { (mEq/litre) }\end{array}$ \\
\hline 1 & 48 & $98 \cdot 4$ & $5 \cdot 4$ & $96 \cdot 8-100 \cdot 0$ \\
2 & 30 & $96 \cdot 3$ & $5 \cdot 3$ & $94 \cdot 3-98 \cdot 6$ \\
3 & 30 & $97 \cdot 8$ & $4 \cdot 8$ & $96 \cdot 0-99 \cdot 6$ \\
4 & 25 & $98 \cdot 1$ & $6 \cdot 6$ & $94 \cdot 4-101 \cdot 7$ \\
5 & 28 & $100 \cdot 6$ & $4 \cdot 7$ & $98 \cdot 8-102 \cdot 4$ \\
6 & 30 & $104 \cdot 5$ & $7 \cdot 0$ & $101 \cdot 9-107 \cdot 2$ \\
7 & 25 & $103 \cdot 3$ & $7 \cdot 0$ & $100 \cdot 4-106 \cdot 2$ \\
10 & 30 & $97 \cdot 4$ & $6 \cdot 0$ & $95 \cdot 2-99 \cdot 7$ \\
\hline
\end{tabular}

TABLE 9

CHANGES IN CONCENTRATION OF SERUM POTASSIUM DURING THE FIRST 10 DAYS OF LIFE IN CAESAREAN BABIES

\begin{tabular}{c|c|c|c|c}
\hline Day & $\begin{array}{c}\text { No. } \\
\text { of } \\
\text { Samples }\end{array}$ & $\begin{array}{c}\text { Arithmetic } \\
\text { Mean } \\
\text { (mEq/litre) }\end{array}$ & $\begin{array}{c}\text { Standard } \\
\text { Deviation } \\
\text { (mEq/litre) }\end{array}$ & $\begin{array}{c}\text { 95\% Confidence } \\
\text { Interval for } \xi \\
\text { (mEq/litre) }\end{array}$ \\
\hline 1 & 45 & $5 \cdot 13$ & $1 \cdot 00$ & $4 \cdot 83-5 \cdot 43$ \\
2 & 27 & $4 \cdot 41$ & $0 \cdot 88$ & $4 \cdot 06-4 \cdot 76$ \\
3 & 26 & $4 \cdot 52$ & $0 \cdot 84$ & $4 \cdot 18-4 \cdot 86$ \\
4 & 25 & $4 \cdot 56$ & 0.90 & $4 \cdot 04-5 \cdot 08$ \\
5 & 27 & $4 \cdot 37$ & $0 \cdot 85$ & $4 \cdot 03-4 \cdot 71$ \\
6 & 26 & $4 \cdot 43$ & $0 \cdot 82$ & $4 \cdot 10-4 \cdot 76$ \\
7 & 25 & $4 \cdot 84$ & 0.80 & $4 \cdot 51-5 \cdot 17$ \\
10 & 25 & $4 \cdot 82$ & 0.76 & $4 \cdot 50-5 \cdot 14$ \\
\hline
\end{tabular}

TABLE 10

CHANGES IN VALUE OF BLOOD CARBON DIOXIDE COMBINING POWER DURING THE FIRST 10 DAYS OF LIFE IN CAESAREAN BABIES

\begin{tabular}{c|c|c|c|c}
\hline Day & $\begin{array}{c}\text { No. } \\
\text { of } \\
\text { Samples }\end{array}$ & $\begin{array}{c}\text { Arithmetic } \\
\text { Mean } \\
\text { (mEq/litre) }\end{array}$ & $\begin{array}{c}\text { Standard } \\
\text { Deviation } \\
\text { (mEq/litre) }\end{array}$ & $\begin{array}{c}\text { 95\% Confidence } \\
\text { Interval for } \xi \\
\text { (mEq/litre) }\end{array}$ \\
\hline 1 & 41 & $19 \cdot 46$ & $3 \cdot 31$ & $18 \cdot 43-20 \cdot 53$ \\
2 & 29 & $18 \cdot 76$ & $2 \cdot 77$ & $17 \cdot 70-19 \cdot 81$ \\
3 & 27 & $17 \cdot 68$ & $2 \cdot 64$ & $16 \cdot 63-18 \cdot 72$ \\
4 & 25 & $17 \cdot 43$ & $3 \cdot 27$ & $15 \cdot 62-19 \cdot 23$ \\
5 & 26 & $18 \cdot 08$ & $3 \cdot 94$ & $16 \cdot 49-19 \cdot 68$ \\
6 & 25 & $17 \cdot 52$ & $3 \cdot 70$ & $15 \cdot 99-19 \cdot 04$ \\
7 & 25 & $18 \cdot 36$ & $4 \cdot 81$ & $16 \cdot 38-20 \cdot 34$ \\
10 & 28 & $18 \cdot 40$ & $4 \cdot 43$ & $16 \cdot 68-20 \cdot 12$ \\
\hline
\end{tabular}


TABLE 11

COMPARISON OF ELECTROLYTES OF BANTU AND NON-BANTU BABIES

\begin{tabular}{|c|c|c|c|}
\hline $\begin{array}{l}\text { Electrolyte } \\
\text { Means }\end{array}$ & $\begin{array}{l}\text { Bantu } \\
\text { Babies }\end{array}$ & $\begin{array}{c}\text { Non-Bantu } \\
\text { Babies } \\
\text { (Gottfried } \\
\text { et al., 1954) }\end{array}$ & $\begin{array}{c}\text { Non-Bantu } \\
\text { Babies } \\
\text { (Spivek, } \\
\text { 1956) }\end{array}$ \\
\hline $\begin{array}{l}\text { Urea (mg./100 ml.) } \\
\text { Na (mEq/litre) } \\
\mathrm{Cl} \text { (mEq/litre) } \ldots \\
\mathrm{K} \text { (mEq/litre) } \ldots \\
\mathrm{CO} \text {. } \\
\quad \text { (mEq/litre) } \ldots\end{array}$ & $\begin{array}{r}26 \cdot 7 \\
135 \cdot 6 \\
96 \cdot 5 \\
4 \cdot 62 \\
19 \cdot 74\end{array}$ & $\begin{array}{l}14 \overline{3} \\
111 \\
- \\
20 \cdot 5\end{array}$ & $\begin{array}{l}20 \\
149 \\
105 \cdot 5 \\
- \\
23\end{array}$ \\
\hline
\end{tabular}

lyte values of caesarean and normal babies showed the following:

Urea. The mean blood urea during the first day of life is significantly higher (significant at $1 / 1,000$ level) in caesarean babies $(34.8 \mathrm{mg} . / 100 \mathrm{ml}$.) than in normal babies $(24 \cdot 2 \mathrm{mg} . / 100 \mathrm{ml}$.).

Serum $\mathrm{Na}$ and $\mathrm{Cl}$. During the first day of life the serum $\mathrm{Na}$ and $\mathrm{Cl}$ in caesarean babies are significantly higher (significant at the 1/1,000 level) than in normal babies. However, on the second and third days these differences are no longer present.

Serum K. On none of the first three days of life is there a significant difference between the mean serum $\mathrm{K}$ of caesarean babies and that of normal babies.

$\mathrm{CO}_{2}$ Combining Power. The $\mathrm{CO}_{2}$ combining power is significantly lower (significant at $5 / 100$ level) in 3-day-old caesarean babies than in 3-dayold normal babies. During the first two days of life, however, there is no significant difference between the two groups.

The relevant tests showed no significant difference between electrolyte values of caesarean babies aged 0 to 12 hours and those aged 12 to 24 hours.

\section{Discussion}

Although the mean electrolyte values obtained in our series may be regarded as fairly representative of the Bantu community where this work was carried out, it should, however, be emphasized that our results are strictly applicable only to newborn babies whose electrolyte estimations are carried out in the laboratory serving the hospital in which the present survey was made. Possibly because of this limiting factor, we are unable to draw any conclusions from a comparison between the values obtained in our series and those obtained in two similar series (Spivek, 1956; Gottfried, Bogin and Levycky, 1954) carried out on babies of
European extraction, the results in all these series differing markedly from one another (Table 11).

From the significant difference tests carried out between the electrolyte values of the normal babies and the caesarean babies in our series, it can be seen that the most striking feature is the difference in the behaviour of the blood urea, the mean blood urea in caesarean, on each of the first three days of life, being significantly higher (significant at $1 / 1,000$ level) than that of normal babies during a corresponding period.

Furthermore, the mean blood urea in caesarean babies continued to rise until it reached an 'abnormally' high level on the fourth day of life, although all the infants remained clinically well. By the tenth day it had, however, fallen markedly, the mean value being almost identical to that found in normally delivered 9-day-old babies (McCance and Widdowson, 1947).

In contrast, the blood urea in our normally delivered babies, having risen initially, began to fall on the third day and remained well within 'normal' limits during the period of investigation, which agrees with the findings elsewhere in the literature (McCance and Widdowson, 1947).

In an attempt to explain the difference in the behaviour of the blood urea between the two groups, one may neglect the fact that their feeding schedules were slightly dissimilar during the first 24 hours of life; although the normal babies received two extra feeds in this period, the extra fluid intake from these was negligible, as mothers only begin to secrete milk freely on the third day after delivery.

The behaviour of the blood urea in the caesarean babies in this series is very similar to that found in premature infants, and also in babies delivered by forceps after a difficult labour (McCance and Widdowson, 1954; Joppich and Wolf, 1958). As in the latter group, the reason for the rising blood urea in infants born by caesarean section is a forced degradation of the tissue proteins. This appears to commence at, or even before delivery, as there is no significant difference between the mean blood urea for the first 12 hours of life and that of the second. In some of these babies it is possible that there may also have been an associated low renal function.

The possible reasons for the forced tissue breakdown have been discussed in the literature (McCance, 1959; McCance and Widdowson, 1954).

\section{Summary}

The mean values for the blood urea, the serum $\mathrm{Na}, \mathrm{Cl}$, and $\mathrm{K}$, and the $\mathrm{CO}_{2}$ combining power 
were determined on each of the first three days of life in 91 babies delivered per vaginam.

The mean values for the blood urea, the serum $\mathrm{Na}, \mathrm{Cl}$, and $\mathrm{K}$, and the $\mathrm{CO}_{2}$ combining power were determined on the first, second, third, fourth, fifth, sixth, seventh and tenth days of life in a group of caesarean babies.

In the caesarean babies the mean blood urea tended to rise from the first to the fourth day of life, reaching 'abnormally high levels'. It then gradually fell so that by the tenth day of life its value was similar to that obtained from a group of normally delivered babies of the same age.

On each of the first three days of life the mean blood urea was shown to be significantly higher in caesarean than in normally delivered babies.

The behaviour of the blood urea was found to be similar to that of premature infants and those delivered by forceps after a difficult labour.

The reasons for the rising mean blood urea are briefly discussed.

My thanks are due to Dr. C. Lavery for permission to carry out this survey in his obstetrical ward; to Dr.
R. Cassel and the staff of the Baragwanath Hospital biochemistry laboratory, who did all the electrolyte estimations; to Miss S. Niven for help with the statistics; to Dr. S. B. Dimson, who was good enough to criticize this paper and to Drs. E. Kahn and S. Wayburne in whose Paediatric Units this work was carried out.

\section{REFERENCES}

Gottfried, S. P., Bogin, M. and Levycky, N. V., Jr. (1954). Blood and electrolyte studies on normal newborn full-term babies. and electrolyte studies on nor

Joppich, G. and Wolf, H. (1958). Reststickstofferhöhungen im Blut von Frühgeborenen in den ersten Lebenstagen. Klin. Wschr., 36, 616 .

King, E. J. and Wootton, I. D. P. (1956). Micro-analysis in Medical Biochemistry, 3rd ed. Churchill, London.

Kunz, H. W. (1953). A technique for obtaining blood specimens and giving transfusions in small infants. $J$. Pediat., 42, 80

McCance, R. A. (1959). The maintenance of stability in the newly born. 1. Chemical exchange. Arch. Dis. Childh., 34, 361. - and Widdowson, E. M. (1947). Blood urea in the first nine days of life. Lancet, $1,787$.

, - (1954). The influence of events during the last few days in utero on tissue destruction and renal function in the first two days of independent life. Arch. Dis. Childh., 29, 495.

and Young W. F. (1941). The secretion of urine by newborn infants. J. Physiol. (Lond.), 99, 265.

Schales, O. and Schales, S. S. (1941). A simple and accurate method for the determination of chloride in biological fluids. $J$. biol. Chem., 140, 879 .

Spivek, M. L. (1956). Micro-chemical blood standards for normal five-day-old newborn infants. J. Pediat., 48, 581 . 